\title{
Application of Bacillus pumilus isolates for management of black rot disease in strawberry
}

\author{
Farid Abd-El-Kareem, Ibrahim E. Elshahawy and Mahfouz M. M. Abd-Elgawad* (D)
}

\begin{abstract}
Background: Black root rot of strawberry plants caused by Rhizoctonia solani, Fusarium solani, and Pythium sp. is a serious disease in Egypt. Biocontrol agents have frequently proved to possess paramount and safe tools against many diseases. The impact of soil treatments with 3 Bacillus pumilus isolates on black root rot disease of strawberry plants caused by R. solani, F., and Pythium sp. under laboratory and field conditions was examined herein on the commonly used 'Festival' strawberry cultivar. To increase the bacterial adhesion and distribution on the roots, each seedling was dipped in bacterial cell suspension at $1 \times 10^{8}$ colony-forming units $/ \mathrm{ml}$ of each separate bacterial isolate for 30 min then mixed with 5\% Arabic gum.

Results: The tested B. pumilus isolates significantly reduced the growth area of these 3 fungi. The two bacterial isolates Nos. 2 and 3 reduced the growth area by more than 85.2, 83.6, and $89.0 \%$ for R. solani, F. solani, and Pythium sp., respectively. Likewise, the 3 bacterial isolates significantly $(P \leq 0.05)$ inhibited the disease under field conditions. Isolates Nos. 2 and 3 suppressed the disease incidence by 64.4 and $68.9 \%$ and disease severity by 65.3 and $67.3 \%$, respectively. The fungicide Actamyl had effect similar to that of the 2 isolates. B. pumilus isolates significantly enhanced growth parameters and yields of strawberry plants; isolates Nos. 2 and 3 raised the yield by 66.7 and $73.3 \%$, respectively.

Conclusions: Bacillus pumilus isolates could effectively manage the black rot disease in strawberry herein. Due to the significant impact of the root rot disease on strawberry yield, B. pumilus should be further tested to manage the disease on strawberry on large scale in Egypt.
\end{abstract}

Keywords: Black root rot disease, Strawberry, Biological control, Bacillus pumilus, Egypt

\section{Background}

An increasing interest in strawberry (Fragaria $x$ ananassa Duchesne) cultivation, as a high-value crop in Egypt, expanded its growing areas to various governorates with different soil capacities. Nevertheless, soil-borne plant pathogens are found in most of the strawberry-planted soils. They can cause too serious diseases to maintain profitable strawberry yield (Abd-Elgawad 2019). Black root rot of strawberry is one such a disease that is caused by one or even more fungal pathogens. In Egypt,

* Correspondence: mahfouzian2000@yahoo.com

Plant Pathology Department, National Research Centre, El-Behooth St., Dokki, Giza 12622, Egypt

\section{Springer Open}

the most serious and damaging fungi on strawberry are Rhizoctonia solani and Fusarium solani together or in addition to Pythium sp. (Abdel-Sattar et al. 2008; AbdEl-Kareem et al. 2019). Many other pathogenic fungi were reported on strawberry in Egypt and worldwide. Main symptoms of black root rot disease include gradual blackening and decay of the plant root system with consequent suppression in vigor and yield of the strawberry plant (Abdel-Sattar et al. 2008). The disease is more aggravated in plants that suffer other stresses such as bad soil drainage and other invading pathogens; e.g., plantparasitic nematodes (PPNs). 
Methyl bromide (MB) alone or in combination with other pesticides has been effectively utilized as a preplant fumigant to suppress many soil-borne pathogens, weeds, and PPNs in Egyptian strawberry fields (AbdElgawad 2019). Nevertheless, this fumigant has recently been banned worldwide for almost all cultivated crops including strawberry due to its hazardous residues (Noling 2016). Generally, growing dissatisfaction with the application of $\mathrm{MB}$ and other chemical pesticides has recently attracted much attention towards biocontrol of plant diseases as a safe and alternative strategy for the frequently risky chemical control (Noling 2016, AbdElgawad 2020). Hence, new safe and effective solutions to control black root rot of strawberry are desperately needed (Abd-El-Kareem et al. 2019). Biocontrol agents included several Bacillus spp., which could not only suppress the causal pathogens but also increase the yields of the treated plant species. One such rod-shaped endospore-forming, Gram-positive, aerobic bacteria of the genus Bacillus is B. pumilus. As others related to the same genus, $B$. pumilus can withstand a range of variable environmental stresses via its spores and consequently adapt easily to diverse habitats. Also, it possesses the distinguished toxin gene ces $B$ and acids that can adhere to diverse surfaces such as their host cells (Potekhina et al. 2011). Moreover, each of two tested B. pumilus strains has demonstrated distinguishable toxins between them (Hoult and Tuxford 1991). Mahmoud et al. (2006) appraised Pseudomonas fluorescens and several Bacillus species as they showed a remarkable efficacy against several pathogenic fungi such as $F$. solani and $R$. solani on peanut roots.

The objective of the present study was to evaluate the effect of soil treatments with three Bacillus pumilus isolates on yield parameters of strawberry plants infected by black root rot disease and on the incidence and severity of the disease.

\section{Methods}

Black root rot pathogens and biocontrol agents

Local pathogenic isolates of $R$. solani, F. solani, and Pythium sp. the causal agents of black root rot disease of strawberry plants and 3 isolates of $B$. pumilus as antagonistic bacteria i.e., Bacillus pumilus (1), B. pumilus (2), and B. pumilus (3) were supplied by the Plant Pathology Department, National Research Centre, Giza, Egypt.

\section{Test of the isolates against the root rot pathogens}

The 3 isolates of $B$. pumilus (1, 2, and 3) were tested against the black root rot pathogens $F$. solani, $R$. solani, and Pythium sp. via the dual culture technique using the method described by Estrella et al. (2007). Each bacterial isolate was cultured (by streaking) at $1 \mathrm{~cm}$ from the edge of a Petri plate containing freshly sterilized Potato
Dextrose Agar (PDA) medium. The same technique of Abd-El-Kareem et al. (2019), but using other factors for disease management, was followed where five $9-\mathrm{cm}$ diameter Petri plates containing PDA medium were replicated per each treatment (fungal species) and the untreated check. The inhibition in mycelial growth of the pathogenic fungi was then estimated via the formula stated by Pandey et al. (2000) as follows:

$R=(C-T / C) \times 100$, where $R=$ mycelial growth reduction (\%) of the pathogen, $C=$ radial growth of the pathogen in control plates $(\mathrm{cm})$, and $T=$ radial growth of the pathogen in dual culture plate $(\mathrm{cm})$.

\section{Field experiments}

Field experiments were carried out under field conditions during 2018/19 and 2019/20 growing seasons at Eldeer village, Toukh Centre, Qalyubia Governorate, Egypt, where soil is light loamy textured with natural infestation. Three plots (each of $1.2 \times 5 \mathrm{~m}$ ) were utilized as replicates for each treatment in addition to the untreated check plots. Each replicate contained 100 strawberry transplants. All strawberry transplants received the same production practices of fertilizers and irrigation regime. The strawberry cultivar Festival was dipped in bacterial cell suspension at concentration of $1 \times 10^{8}$ colonyforming units $(\mathrm{CFU}) / \mathrm{ml}$ of each separate bacterial isolate for 30 min then mixed with 5\% Arabic gum to enhance adhesive capacity and perfect distribution of the bioagent on the outer parts of the treated roots just before transplanting. Seedlings were soaked in just water for the same period to act as untreated check. The experimental layout was complete randomized block of the plots.

\section{Assessment of disease incidence and severity}

Percentages of disease incidence were evaluated 100 days after transplanting as follows:

$$
\text { Disease incidence } \%=\frac{\text { Number of infected plants }}{\text { Total number of plants }}
$$

Disease severity (DS) was recorded at the end of the experiments (5 months after transplanting) based on a 0-5 scale according to Morocko (2006) as follows:

Disease severity $\%=\frac{\sum(\text { Disease grade } \times \text { number of plants in each grade })}{\text { Total number of plants } \times \text { highest disease grade }} \times 100$

The total strawberry yield (ton/feddan) for each treatment was recorded.

\section{Determination of plant growth parameters and yield}

Effect of the tested Bacillus pumilus isolates on fresh and dry weights of the strawberry plants under field conditions was recorded. Also, accumulated yield of 
Table 1 Effect of three Bacillus pumilus isolates on growth area of strawberry black root rot disease under laboratory conditions

\begin{tabular}{|c|c|c|c|c|c|c|}
\hline \multirow[t]{2}{*}{ Treatment } & \multicolumn{2}{|l|}{ F. solani } & \multicolumn{2}{|l|}{ R. solani } & \multicolumn{2}{|l|}{ Pythium sp. } \\
\hline & Growth area $\left(\mathrm{cm}^{2}\right)$ & $\overline{\text { Reduction } \%}$ & Growth area $\left(\mathrm{cm}^{2}\right)$ & Reduction \% & Growth area $\left(\mathrm{cm}^{2}\right)$ & Reduction \% \\
\hline B. pumilus (1) & $18.0 \pm 1.2 b$ & 71.7 & $16.0 \pm 1.0 \mathrm{~b}$ & 74.8 & $17.0 \pm 0.6 b$ & 73.3 \\
\hline B. pumilus (2) & $8.0 \pm 1.0 \mathrm{c}$ & 87.4 & $6.5 \pm 0.3 c$ & 88.2 & $6.0 \pm 1.0 \mathrm{c}$ & 90.0 \\
\hline B. pumilus (3) & $10.0 \pm 0.6 c$ & 83.6 & $9.3 \pm 0.3 c$ & 85.2 & $7.0 \pm 0.6 c$ & 89.0 \\
\hline Control & $63.0 \pm 1.5 \mathrm{a}$ & 0.0 & $63.0 \pm 1.5 \mathrm{a}$ & 0.0 & $63.0 \pm 0.6 \mathrm{a}$ & 0.0 \\
\hline
\end{tabular}

Means \pm standard errors within a column followed by the same letter are not significantly $(P \leq 0.05)$ different according to DNMRT

strawberry (Ton/feddan) in the experimental field was estimated at season-end (30 April, 2020).

\section{Statistical analysis}

Data were exposed to statistical analysis and means were compared utilizing Duncan's new multiple tange test (DNMRT).

\section{Results}

\section{Antagonistic effect of Bacillus pumilus isolates against} black root rot pathogens

The isolates 1, 2, and 3 of B. pumilus significantly reduced the growth areas of the pathogenic fungi (Table 1). Under laboratory conditions, the highest decrease was obtained with the isolates Nos. 2 and 3, which inhibited the growth by more than $83.6,85.2$, and $89 \%$ for F. solani, $R$. solani, and Pythium sp., respectively. Under field conditions, the 3 isolates were also effective but the isolates 2 and 3 reduced the disease incidence by 64.4 and $68.9 \%$ and the disease severity by 65.3 and $67.3 \%$, respectively (Table 2). The fungicide actamyl showed a significant level of fungal suppression similar to that of these 2 bacterial isolates. Isolate no 1 had the least efficacy.

\section{Effect on some vegetative characters}

The 3 isolates of B. pumilus significantly $(P \leq 0.05)$ increased the growth criteria of strawberry plants (Table 3 ). The most effective isolates were B. pumilus Nos. 2 and 3.

\section{Strawberry yield}

The 3 isolates of $B$. pumilus significantly $(P \leq 0.05)$ increased strawberry yield (Table 4$)$. Both B. pumilus Nos. 2 and 3 had the highest yields.

\section{Discussion}

Strawberry is a high value crop grown in Egypt. It is widely infected by many pathogens with a consequent broad distribution of the black root rot disease. Control of such fungal diseases, using different chemical fungicides such as actamyl (used herein) has hazardous side effects on human beings and animals. Hence, other management tactics such as biocontrol agents can constitute a safe alternative of controlling fungal diseases.

It is logic to assume that the yield increase resulted, at least partly, from controlling the fungal pathogens. In this respect, Abd-Elbaky et al. (2012) found that $B$. pumilus applications significantly increased onion bulb yield, whereas Shalaby et al. (2013) reported that B. subtilis treatment enhanced the chlorophyll content, the development of the root and foliage systems, the dry matter of the foliage, and the bulb mass of onion plants grown under field conditions. Kim et al. (2003) reported that 2 Bacillus strains could inhibit the growth of several plant pathogens such as $R$. solani and Pythium sp. Also, Vasebi et al. (2013) showed that Bacillus sp. inhibited the mycelial growth of M. phaseolina by $63.3 \%$ with consequent increase of the peanut growth under 2 soil regimes.

Various mechanisms/modes of action have been proposed to explicate the role of such antagonistic organisms in suppressing the growth with consequent incidence and severity of such pathogens. These could include a number of approaches such as competition, antibiosis, cell wall degradation, mycoparasitism, induced resistance, and rhizosphere colonization capability. Herein, such mechanisms of the bacterial isolates related to Bacillus spp. are usually displayed in terms of

Table 2 Effect of some Bacillus pumilus isolates on black root rot disease of strawberry plants under field conditions

\begin{tabular}{|c|c|c|c|c|}
\hline \multirow[t]{2}{*}{ Treatment } & \multicolumn{4}{|c|}{ Black root rot disease } \\
\hline & Disease incidence & Reduction \% & Disease severity & Reduction \% \\
\hline B. pumilus (1) & $31.0 \pm 0.6 b$ & 31.1 & $34.0 \pm 1.0 \mathrm{~b}$ & 30.6 \\
\hline B. pumilus (2) & $16.0 \pm 0.6 c$ & 64.4 & $17.3 \pm 0.7 c$ & 65.3 \\
\hline B. pumilus (3) & $14.0 \pm 1.0 \mathrm{c}$ & 68.9 & $16.0 \pm 0.6 \mathrm{~cd}$ & 67.3 \\
\hline Actamyl $3 \mathrm{~g} / \mathrm{L}$ & $15.0 \pm 1.5 \mathrm{C}$ & 66.7 & $15.0 \pm 1.2 \mathrm{~d}$ & 69.4 \\
\hline Control & $45.0 \pm 1.5 \mathrm{a}$ & 0.0 & $49.0 \pm 1.0 \mathrm{a}$ & 0.0 \\
\hline
\end{tabular}

Means \pm standard errors within a column followed by the same letter are not significantly $(P \leq 0.05)$ different according to DNMRT 
Table 3 Effect of some Bacillus pumilus isolates on some vegetative characters of strawberry plants under field conditions

\begin{tabular}{lllll}
\hline Treatment & \multicolumn{4}{l}{ Weight $(\mathbf{g})$ / plant } \\
\cline { 2 - 5 } & Fresh & Increase \% & Dry & Increase \% \\
\hline B. pumilus (1) & $180.0 \pm 2.8 \mathrm{~b}$ & 38.5 & $25.0 \pm 1.5 \mathrm{ab}$ & 66.7 \\
B. pumilus (2) & $200.0 \pm 5.7 \mathrm{a}$ & 53.8 & $28.0 \pm 1.0 \mathrm{a}$ & 86.7 \\
B. pumilus (3) & $210 \pm 2.8 \mathrm{a}$ & 61.5 & $27.0 \pm 1.0 \mathrm{a}$ & 80.0 \\
Actamyl 3 g / L & $180.0 \pm 2.8 \mathrm{~b}$ & 38.5 & $22.0 \pm 1.0 \mathrm{~b}$ & 46.7 \\
Control & $130.0 \pm 1.5 \mathrm{C}$ & 0.0 & $15.0 \pm 1.0 \mathrm{C}$ & 0.0 \\
\hline
\end{tabular}

Means \pm standard errors within a column followed by the same letter are not significantly $(P \leq 0.05)$ different according to DNMRT

production of antibiotic-type secondary metabolites and competition with the pathogens for nutrients and space (Sivanantham et al. 2013). Moreover, Bacillus sp. strains are well known from previous studies as plant growthpromoting agents (Wahyudi et al. 2011). Factually, many Bacillus spp. in addition to other fungal pathogens of plants, accounting for the induced system resistance (ISR), can significantly elicit decrease in the incidence of numerous diseases on major host crops (Kloepper et al. 2004). These authors reported that ISR by the Bacillus spp. has been demonstrated against various diseases in both greenhouse and field trials on crops like watermelon, muskmelon, tomato, tobacco, cucumber, bell pepper, sugar beet, Arabidopsis sp., and loblolly pine. Moreover, $B$. pumilus spores generally showed remarkable resistance not only to environmental stresses such as UV light exposure, desiccation, and the presence of oxidizers, but strains of B. pumilus were also found to be resistant to hydrogen peroxide (Kempf et al. 2005).

Surely, it is preferable that an antagonistic organism can antagonize these pathogenic fungi and others using multiple approaches so that it can more effectively control them. For example, 5 PGPR of different genera and characterized with phosphate solubilizing and root colonizing ability could significantly increase tomato seed germination, seedling vigor, and growth and fruit weight. Babu et al. (2015) speculated that such improvements in tomato plants might be partly

Table 4 Effect of three Bacillus pumilus isolates on strawberry yield under field conditions

\begin{tabular}{lll}
\hline Treatment & \multicolumn{2}{l}{ Strawberry yield } \\
\cline { 2 - 3 } & Ton/feddan & Increase \% \\
\hline B. pumilus (1) & $12.0 \pm 0.6 \mathrm{~b}$ & 33.0 \\
B. pumilus (2) & $15.0 \pm 1.0 \mathrm{a}$ & 66.7 \\
B. pumilus (3) & $15.6 \pm 0.9 \mathrm{a}$ & 73.3 \\
Actamyl 3 g / L & $13.0 \pm 0.6 \mathrm{~b}$ & 44.4 \\
Control & $9.0 \pm 0.6 \mathrm{c}$ & 0.0 \\
\hline
\end{tabular}

Means \pm standard errors within a column followed by the same letter are not significantly $(P \leq 0.05)$ different according to DNMRT attributed to the ability of the PGPR to produce indole acetic acid and enhance nutrient uptake and chlorophyll content in the treated plants. Moreover, IPM as a preferable strategy may be followed. So, the antagonistic organism could be applied in conjugation with other control measures. In such a case, a compatibility test should ensure that none of the involved measures are mutually suppressed.

Furthermore, the recent determination of the nucleic acid sequence for the whole B. pumilus GLB197 genome by Zeng et al. (2020) may aid in grasping biological traits relevant to biocontrol against plant pathogens. Eventually, production practices such as crop rotation, tillage, fallow periods, and pesticide uses can directly disrupt populations of antagonistic organisms. These practices can also indirectly and adversely affect antagonists by decreasing their pathogen host(s). Hence, a major confront of conservation biocontrol is that practices intended to protect or enhance suppression of pathogens may not be effective in all field sites because they are dependent on indigenous antagonists (Sharma 2011, Timper 2014). Therefore, indicators will need to be characterized. These may include the existing particular antagonists, which can direct judgments on where it is effective to use conservation biocontrol. In future research, B. pumilus should be examined for managing the root rot disease of strawberry on large scale in Egypt. It should focus on factors that limit suppression of pathogens causing black root rot disease of strawberry plants because changes in abundance of particular antagonists may not affect biocontrol of plant pathogens.

\section{Conclusions}

Biological control agents can usually include beneficial free-living soil bacteria isolated from the rhizosphere. Such agents, namely 3 isolates of $B$. pumilus, proved herein to reduce incidence and severity of black root rot disease on strawberry plants, improve plant health via the disease control, and increase strawberry yield. So, chances which expedite incorporation potentially biocontrol agents into crop management systems should be grasped in the concept of developing new (compatible) application methods or leveraging synergies among agricultural treatments including these bacterial strains. Thus, additional investigations are warranted to further explore relevant criteria and economic feasibility of such bacterial exploitation for the disease control.

\section{Abbreviations}

MB: Methyl bromide; DNMRT: Duncan's new multiple range test;

CFU: Colony-forming units; IPM: Integrated pest management; PDA: Potato Dextrose Agar; PGPR: Plant growth-promoting rhizobacteria; ISR: Induced system resistance; PPNs: Plant-parasitic nematodes 


\section{Acknowledgements}

The authors acknowledge the support in part of this study by the US-Egypt Project cycle 17 (no. 172) entitled "Preparing and evaluating IPM tactics for increasing strawberry and citrus production." This article is derived from the Subject Data funded in part by NAS and USAID, and that any opinions, findings, conclusions, or recommendations expressed in it are those of the author alone, and do not necessarily reflect the views of USAID or NAS. The facilities offered by the National Research Centre are appreciated.

\section{Authors' contributions}

All authors participated in the development and implementation of the research plan and subsequently written it. FA, IE, and MA conceived and designed idea and experimentation. FA developed and performed the computations. IE verified the analytical methods. MA encouraged FA and IE to investigate and supervised the findings of this work. All authors discussed the results and contributed to the final manuscript. The authors have read and approved the final manuscript.

\section{Funding}

Financial support was partially made by both US-Egypt Project related to Science and Technology Development Fund via Project cycle 17 (no. 172) and National Research Centre, Egypt.

\section{Availability of data and materials}

The datasets used and/or analyzed during the current study are available from the corresponding author on reasonable request.

\section{Ethics approval and consent to participate}

Not applicable

\section{Consent for publication}

Not applicable

\section{Competing interests}

The authors declare that they have no competing interests.

Received: 9 September 2020 Accepted: 28 January 2021

Published online: 04 February 2021

\section{References}

Abd-Elbaky AA, Shaltout MA, Abd El-Ghafar NY, Abd-El-Magid MS (2012) Biological control of onion white rot disease using Bacillus spp. isolated from Egyptian soil. Egypt J Phytopathol 40:129-142

Abd-Elgawad MMM (2019) Plant-parasitic nematodes of strawberry in Egypt: a review. Bull NRC 43:7. https://doi.org/10.1186/s42269-019-0049-2

Abd-Elgawad MMM (2020) Optimizing biological control agents for controlling nematodes of tomato in Egypt. Egypt J Biol Pest Cont 30:58. https://doi.org/ 10.1186/s41938-020-00252-x

Abd-El-Kareem F, Elshahawy IE, Abd-Elgawad MMM (2019) Local Trichoderma strains as a control strategy of complex black root rot disease of strawberry in Egypt. Bull NRC 43:160. https://doi.org/10.1186/s42269-019-0206-7

Abdel-Sattar MA, El-Marzoky HA, Mohamed Al (2008) Occurrence of soilborne diseases and root knot nematodes in strawberry plants grown on compacted rice straw bales compared with naturally infested soils. J PI Prot Res 48(2):223-235

Babu AN, Jogaiah S, Ito S, Amruthesh KN, Tran LSP (2015) Improvement of growth, fruit weight and early blight disease protection of tomato plants by rhizosphere bacteria is correlated with their beneficial traits and induced biosynthesis of antioxidant peroxidase and polyphenol oxidase. PI Sci 231: 62-73. https://doi.org/10.1016/j.plantsci.2014.11.006

Estrella FS, Vargas GC, Lopez MJ, Moreno J (2007) Antagonistic activity of bacteria and fungi from horticultural compost against Fusarium oxysporum f. sp. melonis. Crop Prot 26:46-53

Hoult B, Tuxford AF (1991) Toxin production by Bacillus pumilus. J Clin Pathol 44(6):455-458. https://doi.org/10.1136/jcp.44.6.455

Kempf MJ, Chen F, Kern R, Venkateswaran K (2005) Recurrent isolation of hydrogen peroxide-resistant spores of Bacillus pumilus from a spacecraft assembly facility. Astrobiology 5(3):391-405. https://doi.org/10.1089/ast. 2005.5.391
Kim HS, Park J, Choi SW, Choi KH, Lee GP, Ban SJ, Lee CH, Kim CS (2003) Isolation and characterization of Bacillus strains for biological control. J Microbiol 41(3): 196-201

Kloepper JW, Ryu C-M, Zhang S (2004) Induced systemic resistance and promotion of plant growth by Bacillus spp. Phytopathology 94:1259-1266

Mahmoud EY, Shokry YM, Hussin S, Zeinab N (2006) Efficiency of some antagonistic bacteria to reduce incidence damping-off, wilt and peanut root rot. Agric Sci, Mansoura Univ 31(6):3525-3536

Morocko I (2006) Characterization of the strawberry pathogen Gnomonia fragariae, and biocontrol possibilities Ph. D. dissertation. ISSN 1652-6880, ISBN 91-576-7120-6

Noling JW (2016) Nematode management in strawberries, University of Florida publication series no. ENY-031, USA, p 12

Pandey KK, Pandey PK, Upadhyay JP (2000) Selection of potential isolate of biocontrol agents based on biomass production, growth rate and antagonistic capability. Vegetable Sci 27:194-196

Potekhina NV, Streshinskaya GM, Tul'skaya EM, Kozlova YI, Senchenkova SN, Shashkov AS (2011) Phosphate containing cell wall polymers of bacilli. Biochemistry (Mosc) 76:745-754. https://doi.org/10.1134/S0006297911070042

Shalaby ME, Ghoniem KE, El-Diehi MA (2013) Biological and fungicidal antagonism of Sclerotium cepivorum for controlling onion white rot disease. Ann Microbiol 63:1579-1589

Sharma P (2011) Evaluation of disease control and plant growth promotion potential of biocontrol agents on Pisum sativum and comparison of their activity with a popular chemical control agent Carbendazim. J Toxicol Environ Health Sci 3:127-138

Sivanantham T, Rasaiyah V, Satkunanathan N, Thavaranjit AC (2013) In vitro screening of antagonistic effect of soil borne bacteria on some selected phytopathogenic fungi. Arch Appl Sci Res 5(1):1-4

Timper P (2014) Conserving and enhancing biological control of nematodes. J Nematol 46(2):75-89

Vasebi Y, Safai N, Alizadeh A (2013) Biological control of soybean charcoal root rot disease using bacterial and fungal antagonists in vitro and greenhouse condition. J Crop Prot 2(2):139-150

Wahyudi AT, Astuti RP, Widyawati A, Meryandini A, Nawangsih AA (2011) Characterization of Bacillus sp. strains isolated from rhizosphere of soybean plants for their use as potential plant growth for promoting rhizobacteria. $J$ Microbiol Antimicrob 3:34-40

Zeng Q, Xie J, Zhang X, Li Y, Wang Q (2020) Complete genome sequence data of Bacillus pumilus GLB197, an effective antagonist of grape downy mildew. Data Brief 30:105423. https://doi.org/10.1016/j.dib.2020.105423

\section{Publisher's Note}

Springer Nature remains neutral with regard to jurisdictional claims in published maps and institutional affiliations.

\section{Submit your manuscript to a SpringerOpen ${ }^{\circ}$ journal and benefit from:}

- Convenient online submission

- Rigorous peer review

- Open access: articles freely available online

High visibility within the field

- Retaining the copyright to your article

Submit your next manuscript at $\boldsymbol{\nabla}$ springeropen.com 